6. František Vencovský, Dějiny českého ekonomického myšlení do roku 1948. Brno: Nadace Universitas Masarykiana, 1997.

7. Ilona Bažantová, Czech economist Karel Engliš and his relation to the Austrian School in the first half of the $20^{\text {th }}$ century. Prague Economic Papers (at print).

8. Karel Engliš, Soustava národního hospodářství I., II. Praha: Melantrich 1938.

Kevin Biwott

KUSCCO Ltd Nairobi

E-mail: sirbekev@yahoo.com

Irene Asienga, Dr.

School of Business and Economics

Kabarak University

E-mail:ikoech@yahoo.com

Firtz Mulumia Gerald Oketch

School of Business and Economics

Kabarak University

E-mail: firtz.mulumia@outlook.com

Renny K. Mutai

PhD Candidate, University of Nairobi

E-mail:rmutai@gmail.com

\title{
Government regulation and performance of small saccos in Nairobi City County, Kenya
}

\begin{abstract}
Direct government regulation of Saving and Credit Cooperative societies (Saccos) in Kenya came about through legislation enacted by the Kenyan parliament, the Sacco Act of 2008. The regulations were necessitated by the need to give proper structures and prudential standards to Saccos especially those involved in deposit taking activities referred to as Front Office System Administration (FOSA). The FOSAs carry out banking business with members of the public most of whom are not their members. Since the Saccos were not regulated by Central Bank of Kenya or the Banking Act, the government forged direct regulation through Sacco Society Regulation Authority (Sasra). This study therefore sought to investigate the effect of government regulation on performance of small Saccos in Nairobi City County, Kenya. Specifically the study sought to determine the effect of regulation requirements: statutory deposit fund, management qualification, and quality and membership on the performance of small Saccos. The study used survey research design while the target population comprised of all small licensed deposit taking Saccos in Nairobi City County. Data was collected by use of structured questionnaires. The main finding of the study is that implementation of government regulations has improved performance of the Saccos. Statutory deposit regulations positively affect Sacco liquidity while members also showed confidence in qualified managers based on performance but felt that membership regulation is punitive. In conclusion the regulation has positive effects on Saccos and hence the study recommends compliance by Saccos to the regulations.

Key words: Regulation, Saccos performance, Sacco Society regulation Authority (Sasra)

\subsection{Introduction}

The co-operative nature of the Kenyan people can be traced to the pre-colonial traditional societies

where people cooperated in several activities such as hunting, farming, building houses, taking care of animals and in many other important chores. The
\end{abstract}


first formal Savings and Credit Co-operative Society (Sacco) in Kenya was at Lumbwa, Rift Valley in 1908. The Lumbwa Sacco was formed by white settlers to enable its members bargain for better fertilizer and seeds prices (Chebor, 2008).

Kenya is regarded as the leading country in Africa in co-operative movement (ACCOSCA, 2013). There are 10,800 registered co-operatives Societies with a membership of 6 million. Co-operatives have created about 250,000 direct employments and 5.9 million people benefit indirectly. The sector holds $31 \%$ of total national savings and contributes $46 \%$ of the national Gross Domestic Product (GDP). It has $70 \%$ of the coffee market, $76 \%$ dairy, $90 \%$ pyrethrum, and 95\% of cotton (Ochanda, 2013).

The size of a Sacco is determined by financial structure, asset quality, rates of return and cost, liquidity and signs of growth among others. In Kenya, Saccos Regulatory Authority (Sasra) determines the size of Saccos, regulates and cluster them on the basis of loans, deposits and asset base (Njuguna, 2012). Small Saccos are considered to be those with asset base of below one billion. The Saccos with savings between one and three billon are considered medium while Saccos with over four billion are large Saccos.

Table 1.1 Sacco Performance Measure

\begin{tabular}{|l|c|c|c|c|c|c|c|c|c|}
\hline \multirow{2}{*}{ CATEGORY } & & \multicolumn{2}{|c|}{ SACCO NO. } & \multicolumn{2}{c|}{ ASSETS } & \multicolumn{2}{c|}{ DEPOSIT } & \multicolumn{2}{c|}{ LOANS } \\
\cline { 2 - 10 } & $\begin{array}{c}\text { Asset } \\
\text { Size }\end{array}$ & $\mathbf{2 0 1 1}$ & $\mathbf{2 0 1 2}$ & $\mathbf{2 0 1 2}$ & $\mathbf{2 0 1 1}$ & $\mathbf{2 0 1 2}$ & $\mathbf{2 0 1 1}$ & $\mathbf{2 0 1 2}$ & $\mathbf{2 0 1 1}$ \\
\hline LARGE & $\begin{array}{c}\text { Above } \\
\text { Kshs 4B }\end{array}$ & 9 & 10 & 94,439 & 80,198 & 71,631 & 53,928 & 78,164 & 58,996 \\
\hline MEDIUM & $\begin{array}{c}\text { Kshs } \\
\text { 1B-4B }\end{array}$ & 38 & 41 & 79,982 & 70,003 & 55,720 & 41,526 & 57,978 & 51,632 \\
\hline SMALL & $\begin{array}{c}\text { Below } \\
\text { Kshs 1B }\end{array}$ & 77 & 73 & 27,485 & 27,403 & 18,734 & 31,981 & 18,275 & 24,915 \\
\hline TOTAL & & $\mathbf{1 2 4}$ & $\mathbf{1 2 4}$ & $\mathbf{2 0 1 , 9 0 6}$ & $\mathbf{1 7 7 , 6 0 4}$ & $\mathbf{1 4 6 , 0 8 5}$ & $\mathbf{1 2 7 , 4 3 5}$ & $\mathbf{1 5 4 , 4 1 7}$ & $\mathbf{1 3 5 , 5 4 3}$ \\
\hline
\end{tabular}

Source: Sasra

The Co-operative Societies Ordinance Act of 1931 by the colonial government marked the first intervention for cooperatives in Kenya by the government (ICA, 2002). The legislation of cooperatives in Kenya has been strong and metamorphosed from the Cooperative Ordinance Act of 1931 which was repealed in 1932 and later in 1945. The colonial government in 1946 established Department of Cooperatives to register Saccos. The first law governing Saccos was Cap 490 of Kenya formulated in 1966 based on International Labour Organization (ILO) and this was later replaced by Co-operative Societies Act, 12 of 1997.

Direct government regulation of Saccos came about through legislation enacted by the Kenyan parliament; the Sacco Act of 2008. The regulations were necessitated by the need to give proper structures and prudential standards to Saccos especially those involved in deposit taking activities referred to as Front Office System Administration (FOSA). The
FOSAs carry out banking business with members of the public most of whom are not their members. Since the Saccos were not regulated by Central Bank of Kenya or the Banking Act, the government forged direct regulation through Sasra.

The Sacco Act No. 14 of 2008 was expected affect operation and reporting of Saccos. The Saccos must deposit $10 \%$ of their total member deposits or a minimum of Kenya shillings ten million to a statutory deposit fund in Sasra that is meant to act as insurance for the deposits. The Saccos are also required to hire qualified staff for their book keeping and a Chief Executive Officer of a Sacco is required to have a minimum of a masters degree in businessrelated field. The Act requires that all members of a Sacco be homogeneous. This implies that Saccos should be composed of Kenyan members with the same background (Kioko, 2012).

These changes in regulations are expected to have both short- and long- term effects on the Sac- 
cos. The impact will mainly be on loaning services offered by the Saccos, the savings deposit, the composition of Sacco membership and the qualification of Sacco staff as these issues are directly addressed by the Act.

Based on the foregoing this study sought to investigate the effect of government regulation on performance of small Saccos in Kenya. Specifically the study sought to:

i) Investigate the effect of statutory deposit fund requirement on performance of small Saccos in Nairobi City County

ii) Determine the effect of management qualification on the performance of small Saccos in Nairobi City County

iii) Determine the effect of membership regulation requirements on performance of small Sacco in Nairobi City County

Previous studies (Zeuli and Cropp 2013, Gordon and McClathey 1999, Grossman and Olive 2002, Huppi and Fedder 2010, Kioko 2012, and Wanyoike 2013) focused mainly on financial performance of Saccos. Empirical studies for Kenya (Kioko 2012, and Wanyoike 2013) have not looked at specific aspects of these regulations particularly the effect of statutory deposit fund requirements and Sacco membership on performance of the Saccos. The purpose of this study therefore was to investigate the impact of direct control by government (by regulation requirements: statutory deposit fund, management qualification, and quality and membership) through regulators like Sasra on the performance and sustainability of small Saccos in Nairobi City County.

\subsection{Research Hypothesis}

In an attempt to achieve the above objectives, this study developed the following null hypotheses

i. $\mathrm{Ho}_{1}$ : Statutory deposit fund requirement has no significant effect on performance of small Saccos in Nairobi City County

ii. $\mathrm{Ho}_{2}$ : Management qualification and quality has no significant effect on the performance of small Saccos in Nairobi City County

iii. $\mathrm{Ho}_{3}$ : Membership regulation requirements has no significant effect on performance of small Saccos in Nairobi City County

\subsection{Literature Review}

2.1 Theoretical Review
Regulation is a rule or law designed to govern conduct. It functions by creating limits, constraints, duty or responsibility. It can take many forms; legal restrictions promulgated by a government authority, contractual obligations that bind many parties, self-regulation by an industry such as through an association, social regulation, co-regulation, thirdparty regulation, certification, accreditation or market regulation (Cunningham 2007).

The regulation of Saccos has been introduced in many places around the world. India adopted a regulation that gave cooperatives a hybrid business alliance system that has enabled the cooperative owned business to grow to big empire of companies and own vast properties around and outside India (Fischer and Cuevas, 2006). UNISAP Federation is responsible for Sacco control in Mexico and has seen Saccos grow to have lower risk than commercial banks. The Saccos have hence grown and patronizes more than $60 \%$ of the total Mexican rural population (Be'roff, 2008).

The regulation of cooperatives in Brazil was marked by legislation in 1890 to address involvement of military personnel in cooperatives. Canada adopted a data envelopment analysis (DEA) system that checks asset to equity ratio and a modified Z-score of all credit unions and compares them weekly to a fixed score. This has made Saccos to operate prudently hence fewer cases of cooperative failure (Pille and Puradi, 2002).

In U.S.A. credit unions are regulated by non banking financial institution laws securities and exchange Act. The system consists of complex rules that guide the operations of credit unions in the country. The system was introduced on the aftermath of great depression of 1929 and was meant to improve the public confidence on financial institution (Kumar et al, 1997).

In Egypt, regulation of credit union is controlled strictly as the government sets the ceiling interest rate for issuing loans. Credit unions are also registered and managed directly by Ministry of Economy.. The regulations are however, too stringent hence lead to the rise of an underground lending market as unregistered individuals come together and loan money amongst themselves (Mahmoud and Wright, 2000).

The Sacco regulation 2005 of Tanzania restricted 
Sacco with stringent rules on composition and operations of Saccos. This has caused a steady drop in the number of Saccos and other microfinance institutions have taken over. In this case of stringent regulation, deregulation was direly needed to revive the sector (Rubambey, 2005).

\subsection{Empirical Review}

2.2.1 Statutory Deposit Fund Requirement on Savings

Individual countries adopt statutory deposit fund for different reasons; for instance in developing countries, a common goal is to expand the reach of financial management system and to increase the flow of credit by minimizing depositor's doubts about the financial institutions ability to redeem depositor's claims when funds are needed (Fischer and Cuevas, 2006). Hence the scheme bolsters depositor's faith in the stability of the SACCOs financial sector.

Gordon and McClatchey (1999) investigated the behavioral change after introduction of reserve deposit by credit unions. They observed that the introduction of insurance deposit did not increase risk taking behavior by the credit unions as it was expected by their objectives; "A time series tests employing industry average financial ratios for federal and state credit unions did not support the increased risk-taking hypothesis." This implies that the credit unions did not switch to a frenzy of loans issuing or saving increasing procedures although they were already insured and would be compensated in case of insolvency.

Honohan and Klingebiel (2003) analyzed the impact of blanket guarantees and other crisis management strategies on the full fiscal costs of resolving financial system distress. Their analysis of 40 credit unions that experienced financial crisis between 1980 and 1997 indicated that unlimited deposit guarantees with open-ended liquidity support and capital forbearance significantly increased the ultimate fiscal cost of revolving financial crisis.

Demirgus and Huizinga (2004) used SACCO level data covering 43 SACCOs for a period of between 1990-1997 to study deposit discipline by modeling deposit interest rates. They found out that explicit insurance does lower Sacco's financial risk and does make interest payment less sensitive to individuals Sacco risk and liquidity. Government guarantees never completely extinguish market discipline and still stability can be undermined if SACCOs deposit insurance managers do not exert more discipline that is required.

The quality of a nation's contracting environment limits the contribution that variations in regulatory structures can improve both sustainable economic and microeconomic growth. Recent adaptors of statutory deposit fund include Africa and Latin America countries with low levels of financial development and government accountability. Using time series data for 58 credit unions, Cull et al (2005) found that explicit statutory deposits favorably impact the levels and volatility of financial activity only in the presence of a strong institutional development.

\subsubsection{Management Qualification and Quality}

Both Boards of Directors and senior management are accountable for the internal governance of SACCOs (Drake, 2002). The Board of Directors is the supreme authority and the highest decision making in SACCOs. While it has a duty to the Boards of Directors, senior management must be accountable for the implementation of policies, preparation of the budgets, strategic plans and achievement of predetermined targets specified in the strategic plans.

Grossman and Olive (2002) analyzed the usefulness of one share one vote systems on the control of co-operatives for maximum utilization. They found that the system provided an important front for selection of efficient management team since everyone had an equal chance to air his or her views hence decisions made are for the best of a company. They assumed two types of control benefits - benefits to security holders and private benefits to the controlling party. One share-one vote maximized the benefits to security holder relative to benefits of the controlling party hence encouraged the efficient management team. They found that the cooperative systems of running organizations produced better results and ensured that the shareholder's agents act in the best interest of share holders.

A key underlying factor behind merger activities is the beneficial side effect of economy of scale for which Mckillop et al (2002) noted was a considerable scope which in turn allowed credit unions to diversify into a range of product and services. The management of these ranges of highly sophisticated 
portfolio of investments needed highly qualified managers to run efficiently. Increasing members of credit unions, particularly to those that have merged to form larger entities, employed professional personnel in key roles such as Managers as regulatory requirement became a reality. There is a downside to merger, consolidation drive in that it is arguable that such a move will ultimately threaten the viability of smaller SACCOs, forcing them into merger and possibly affecting new start up rates of borrowing of their credit facilities.

The credit union ethos has always been as self help financial cooperatives and the push to merger, led to larger financial organizations professionally managed which competed effectively with other financial institutions.

Although policies are not a requirement in the provision of the Act, all SACCOs are required to have by laws that define at the minimum the field and requirement for membership, scope of activities, duties and responsibilities of the Board members, committees and operational staff. In the absence operational policies, some activities like setting interest rates on loans and saving products have been institutionalized in the bylaws, (Ademba 2011). Because of these, SACCOs are forced to refer to the AGM for operational decisions that can be easily made by senior management and hence SACCOs have kept their interest rates below market rates despite higher borrowing costs, stiff competition, fluctuating inflation rates and changing cost structures

The study by Wanyoike (2013) sought to investigate the effect on staff competence, quality of board of directors and corporate governance on financial performance of Saccos in Kenya with focus on Nairobi County. Using a population of 34 deposit taking Saccos the study finds that the quality of the Board of Directors, Sacco staff competence and corporate governance had a strong influence on the financial performance of the Saccos. The study concludes that all the variables of the study were important factors in financial performance of the Saccos.

The governance structure of SACCOs assumes its legitimacy via the votes of its members who surrender their wealth or administration to board of management (Muchemi, 2005). The board can therefore make or break the wealth acquisition aspirations of the SACCO membership. One way through which SACCOs can improve management financial decisions is through provision of financial education to its members. If correctly applied, the knowledge can positively impact on the running of these SACCOs.

2.2.3 Membership Regulation Requirements

Kioko (2012) studied the effect of SASRA regulation on Sacco's financial performance in Kenya. The study used secondary data collected from the financial statements of the SACCOs to obtain information on annual earnings of 30 SACCOs registered under SASRA. A linear regression model of SACCO's return on assets versus SASRA regulations was applied to examine the relationship between the variables. The study found that higher capital requirements and increase in management efficiency impacted positively on SACCO's profitability in the post- capital regulation period.

Huppi and Fedder (2010) in their study of the role of groups and credit cooperative in rural lending concluded that co-operatives served members only and took deposits to ensure loaned members do not default. They found that successful group lending scheme work well with groups that are homogeneous and jointly liable for defaults. The practice of denying credit to group members in case of default by one of them is the most effective and least costly way of enforcing joint liability. Another way to encourage members to repay was viewed requiring mandatory deposit that is reimbursed only when all borrowers have repaid their loans. They concluded that since Saccos are a source of wellbeing to the rural members as they have a limited access to financial services from banks or other financial institutions checks should be put to ensure its continuity.

\subsection{Conceptual Framework}

Figure 2.1 below shows the relationship between the dependent and independent variables. The independent variables in the study include the statutory deposit requirement as a regulation to Saccos that each Sacco submit to the government $10 \%$ of the total deposit by members with a minimum of Ksh 10 Million to act as insurance deposit: management qualification and quality requirement that Sacco board of directors must have an understanding of business operations 
and that the C. E.O's minimum qualification be a masters degree and good conduct. Finally the membership requirement regulation that dictates that all the members that join a Sacco must be people with the same interest and Sacco can only carry out business with its members. The dependent variable in this case is the financial performance of Saccos.

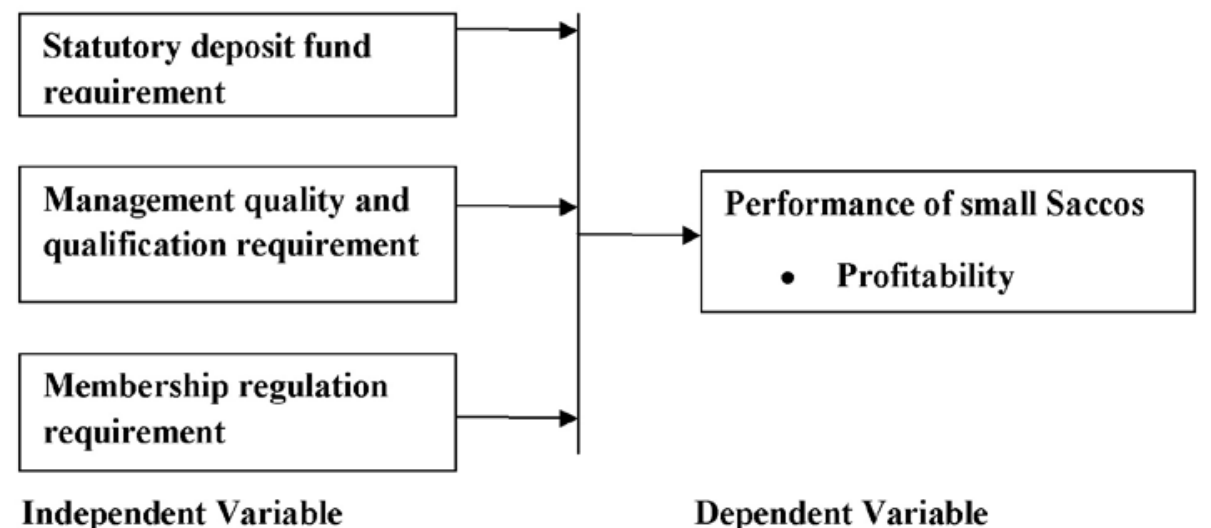

Figure 2.1 Conceptual Framework

\subsection{Research Methodology}

\subsection{Research Design}

The research problem was studied using survey research design. This research design was relevant to the study because it gives insight into the process of obtaining responses from or about all of the members of the population in order to establish as many relationships as possible between the variable of the study as a basis for general findings (Kothari, 2012). The study was therefore able to generalize the findings to a larger population.

\subsection{The Sample}

The population for the study comprised of all the Saccos in Nairobi City County. The target population for this study was staff of all 11 small licensed deposit taking Saccos in Nairobi City County. The study used a sample size 36 following the formula by Kotler (2001).

\subsection{Data Collection and Analysis}

The study used primary data which was collected by useof questionnaire. The questionnaire was designed to gather information relevant to the research questions and to be administered to the sample under study. Data was then analyzed using descriptive and inferential statistics.

\subsection{Analysis, Presentation and Discussion}

This section summarises the results and findings of the study. The main objective of the study was to investigate the effect of government regulation on performance of small Saccos in Kenya. Specifically the study sought to investigate the effect of statutory deposit fund requirement, management qualification and membership regulation requirements on performance of small Saccos in Nairobi City County.

\section{1 Baseline Characteristic of Data}

Table 4. 1 Baseline Characteristic of Data

\begin{tabular}{|l|c|c|c|c|}
\hline \multicolumn{1}{|c|}{ Variables } & Classification & Frequency & Percent & Valid Percent \\
\hline \multirow{4}{*}{ Position held } & Manager & 4 & 11.1 & 11.1 \\
\cline { 2 - 5 } & Staff & 32 & 88.9 & 38.9 \\
\cline { 2 - 5 } & Total & 36 & 100 & 100 \\
\hline \multirow{3}{*}{$\begin{array}{l}\text { Duration of association with } \\
\text { the Sacco }\end{array}$} & Below 1 year & 10 & 27.8 & 27.8 \\
\cline { 2 - 5 } & $1-5$ years & 15 & 41.7 & 41.7 \\
\cline { 2 - 5 } & $5-10$ years & 8 & 22.2 & 22.2 \\
\cline { 2 - 5 } & $>10$ years & 3 & 8.3 & 8.3 \\
\cline { 2 - 5 } & Total & 36 & 100 & 100 \\
\hline
\end{tabular}

From the findings, most of the respondents (89\%) worked for the Saccos as ordinary staff while $11 \%$ of the total responses were managers. Concerning the work- ing period the modal period that the respondents have worked in Sacco sector was between one and five years with a mean of 2.11 and the middle age being 6 years of 
work experience. A total of 10 staff or $27.8 \%$ had worked for less than one year while $22.2 \%$ and $8.3 \%$ had worked for five to ten years and over ten years respectively. Over $70 \%$ of the respondents had worked for over one year. This pointed out that they had the knowledge and experience of their respective departments and therefore offered credible information towards the study.

\subsection{Statutory Deposit Fund Requirements}

The first objective of the study was to investigate the effect of statutory deposit fund requirement on performance of small Saccos in Nairobi City County. Table 4.2 summarises the effect of statutory deposit fund requirement on Sacco liquidity and amount of deposit.

Table 4.2 Effects of Statutory deposit requirement on Small Saccos

\begin{tabular}{|l|c|c|c|c|c|c|}
\hline \multicolumn{1}{|c|}{ Statements } & $\begin{array}{c}\text { Strongly } \\
\text { Agree }\end{array}$ & Agree & Neutral & Disagree & $\begin{array}{c}\text { Strongly } \\
\text { Disagree }\end{array}$ & Totals \\
\hline $\begin{array}{l}\text { Statutory deposit requirement affects } \\
\text { Sacco liquidity }\end{array}$ & $44.40 \%$ & $33.30 \%$ & $19.40 \%$ & $2.80 \%$ & $0.00 \%$ & $100.00 \%$ \\
\hline $\begin{array}{l}\text { Statutory deposit requirement in- } \\
\text { crease members' deposit }\end{array}$ & $23.50 \%$ & $36.50 \%$ & $7.60 \%$ & $23.50 \%$ & $8.80 \%$ & $100.00 \%$ \\
\hline $\begin{array}{l}\text { Statutory deposit requirement is not } \\
\text { affordable to small Saccos }\end{array}$ & $29.40 \%$ & $20.60 \%$ & $14.70 \%$ & $20.60 \%$ & $14.70 \%$ & $100.00 \%$ \\
\hline
\end{tabular}

Three statements were designed on a five point Likert scale to investigate the effect of statutory deposit requirement on small Saccos in Nairobi City County (see table 4.2 above). A total of $44.4 \%$ of the respondents strongly agreed that statutory de-

posit requirements affects liquidity of small Saccos, $23.5 \%$ strongly agreed that statutory deposit requirement increases the amount of deposit while 29.4\% indicated that Statutory deposit requirement is not affordable to small Saccos.

Chi-Square Tests

\begin{tabular}{|l|r|r|r|}
\hline & \multicolumn{1}{|c|}{ Value } & Df & Asymp. Sig. (2-sided) \\
\hline Pearson Chi-Square & $6.431^{\mathrm{a}}$ & 6 & .377 \\
\hline Likelihood Ratio & 7.067 & 6 & .315 \\
\hline Linear-by-Linear Association & .006 & 1 & .936 \\
\hline N of Valid Cases & 36 & & \\
\hline
\end{tabular}

a. 9 cells (75.0\%) have expected count less than 5 . The minimum expected count is. 11 .

Table 4.2 above shows that $77 \%$ of those interviewed agree that the statutory deposit requirement affects liquidity while $20 \%$ were neutral and the remaining three percent said that it had no effect. On members deposits, $23.5 \%$ of the respondents strongly agree that the regulation increased members deposit and $36.5 \%$ others also agree while $23.5 \%$ disagreed that and $9 \%$ strongly disagreed. However $7 \%$ were neutral. Half of those interviewed agree that the statutory deposit is not affordable to small Sac-

cos, $20 \%$ of them disagreed while $14 \%$ strongly disagree and $14 \%$ were neutral. These findings are in agreement with (Fischer \& Cueveas, 2006) who found out that insurance funds introduction does affect growth in credit unions and that it bolsters depositor's faith in stability of Saccos. Our findings that deposits in the Saccos increased after introduction of statutory deposit requirement (with $60 \%$ being in agreement) is in line with this study.

Table 4.2.1 Chi-Square Tests Effect of Statutory Regulation on the Amount of Deposit

\begin{tabular}{|l|r|r|r|}
\hline & \multicolumn{1}{|c|}{ Value } & \multicolumn{1}{|c|}{ Df } & Asymp. Sig. (2-sided) \\
\hline Pearson Chi-Square & $15.712^{\mathrm{a}}$ & 8 & .047 \\
\hline Likelihood Ratio & 17.839 & 8 & .022 \\
\hline Linear-by-Linear Association & 5.340 & 1 & .021 \\
\hline N of Valid Cases & 34 & & \\
\hline
\end{tabular}

a. 9 cells (100.0\%) have expected count less than 5. The minimum expected count is.35.

Half of the managers interviewed agree that the statutory deposit is not affordable to small Saccos as shown above; the significance level was about $4.7 \%$

showing that there is not much difference between expected and observed findings 


\subsubsection{Spearman rank correlation on the relationship between statutory deposit factors}

\begin{tabular}{|c|c|c|c|c|c|c|}
\hline & & Liquidity & Deposit & $\begin{array}{l}\text { Cost In- } \\
\text { crease }\end{array}$ & Affordability & Profit \\
\hline \multirow{3}{*}{$\begin{array}{l}\text { Statutory deposit require- } \\
\text { ment effect on liquidity }\end{array}$} & C. Coefficient & 1 & $.540^{* *}$ & $.372^{*}$ & $.511^{* *}$ & 0.229 \\
\hline & Sig. (1-tailed) & & 0 & 0.015 & 0.001 & 0.097 \\
\hline & $\mathrm{N}$ & 36 & 34 & 34 & 34 & 34 \\
\hline \multirow{3}{*}{$\begin{array}{l}\text { Regulation has led to in- } \\
\text { crease in the amount of } \\
\text { deposits }\end{array}$} & C. Coefficient & $.372^{*}$ & 1 & 0.162 & $.341^{*}$ & 0.263 \\
\hline & Sig. (1-tailed) & 0.015 & 0.18 & . & 0.024 & 0.067 \\
\hline & $\mathrm{N}$ & 34 & 34 & 34 & 34 & 34 \\
\hline \multirow{3}{*}{$\begin{array}{l}\text { Statutory deposit has in- } \\
\text { creased cost of operations }\end{array}$} & C. Coefficient & $.511^{* *}$ & $.407^{* *}$ & 1 & $.341^{*}$ & $.438^{* *}$ \\
\hline & Sig. (1-tailed) & 0.001 & 0.008 & 0.024 & & 0.005 \\
\hline & $\mathrm{N}$ & 34 & 34 & 34 & 34 & 34 \\
\hline \multirow{3}{*}{$\begin{array}{l}\text { Statutory deposit fee } \\
\text { amount is not affordable } \\
\text { to small Saccos }\end{array}$} & C. Coefficient & 0.229 & $.410^{* *}$ & 0.263 & 1 & $.438^{* *}$ \\
\hline & Sig. (1-tailed) & 0.097 & 0.008 & 0.067 & 0.005 & \\
\hline & $\mathrm{N}$ & 34 & 34 & 34 & 34 & 34 \\
\hline \multirow{3}{*}{ Profitability of the Sacco } & C. Coefficient & -0.151 & -0.206 & 0.073 & $-.433^{* *}$ & 1 \\
\hline & Sig. (1-tailed) & 0.2 & 0.129 & 0.345 & 0.007 & 0.038 \\
\hline & $\mathrm{N}$ & 33 & 32 & 32 & 32 & 32 \\
\hline
\end{tabular}

Table 4.2.2above shows that there exist high correlation among the various statutory deposit and their effects on Sacco performance. This correlation among various factors demonstrates that statutory deposit was significant correlated to factors evaluated. Strong correlation of $97 \%$ confidence level was noted.

Statutory deposit fund requirement is a sum deposited for security to a regulator. In this study, the introduction of this regulation has had an effect on Sacco performance. The increase in deposits increased liquidity and hence an increase in loaning activity. This is contrary to the findings by Gordon and McClatchy (1999) on behavior change after introduction of reserve deposit on credit unions. Their

\subsection{Management Qualification}
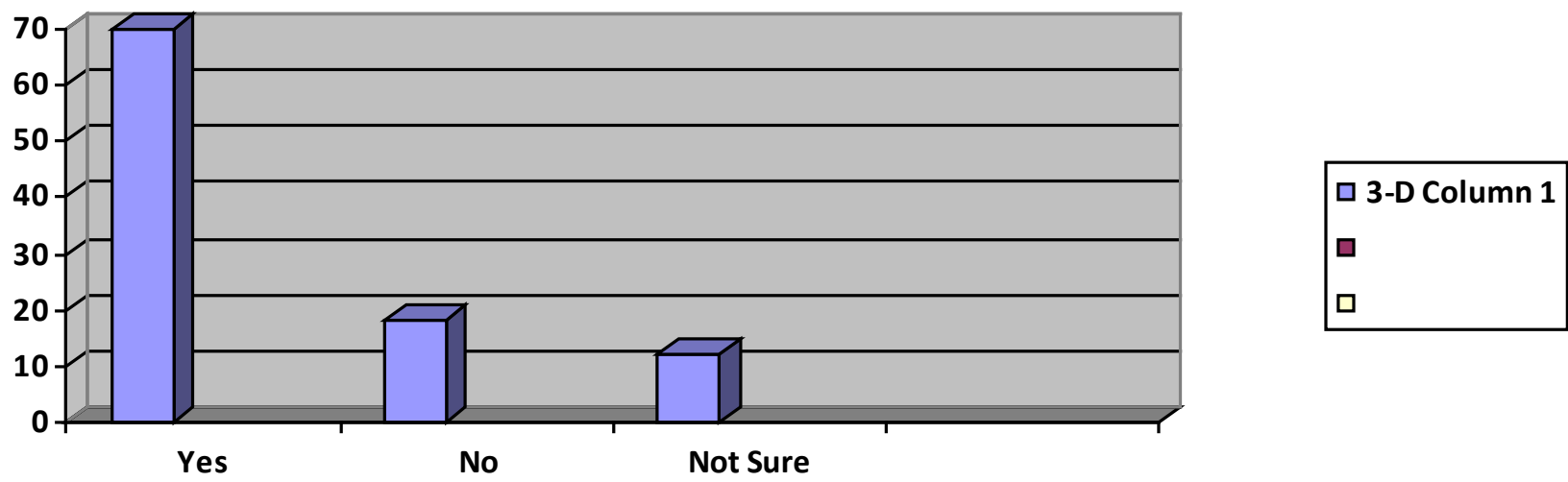

Figure 4.3 management quality and qualification requirement

Seventy $70 \%$ of those interviewed supported the introduction of management quality requirement while $18 \%$ were against the regulation and findings were that the unions did not increase risk taking behavior as they had hypothesized. This implies that credit unions did not switch to a frenzy of issuing loans even though the savings were insured and would be compensated in any eventuality.

The effect caused by transfer of money to the government has increased confidence in Saccos and hence improved liquidity. This is in agreement with Folkerts and Lindsen (1998) who found out that in case of financial problems of financial institutions with public insurance (fund) pushes government to bailout and hence security is high and difficult for government to resist helping out as stakeholders are of public in nature.
$12 \%$ were not sure. A chi-square test is presented. The management qualification and quality requirement was supported by most of those interviewed. It 
was their opinion that such management would improve performance. This is in agreement with (Andrew, 2008) who found out that ultimately the credit unions became strong, secure and professionally managed. A policy framework on new management was introduced In Europe which led to growth in the sector and emergence of strong credit unions capable of meeting credit of a wide range of persons.

Table 4.3. Management quality and qualification requirement factors

\begin{tabular}{|l|c|c|c|c|c|c|}
\hline & $\begin{array}{c}\text { Strongly } \\
\text { Agree }\end{array}$ & Agree & Neutral & Disagree & $\begin{array}{c}\text { Strongly } \\
\text { Disagree }\end{array}$ & Totals \\
\hline Managers give quality service to Saccos & $31.40 \%$ & $37.10 \%$ & $17.10 \%$ & $5.70 \%$ & $8.60 \%$ & $100.00 \%$ \\
\hline $\begin{array}{l}\text { Managers qualification is important for Saccos } \\
\text { performance }\end{array}$ & $52.90 \%$ & $11.80 \%$ & $0.00 \%$ & $5.90 \%$ & $29.40 \%$ & $100.00 \%$ \\
\hline $\begin{array}{l}\text { Management quality and requirement is of } \\
\text { more benefit compared to cost }\end{array}$ & $11.80 \%$ & $29.40 \%$ & $11.80 \%$ & $29.40 \%$ & $17.60 \%$ & $100.00 \%$ \\
\hline $\begin{array}{l}\text { Qualified managers are expensive for small Sac- } \\
\text { cos }\end{array}$ & $32.40 \%$ & $17.60 \%$ & $17.60 \%$ & $14.70 \%$ & $17.60 \%$ & $100.00 \%$ \\
\hline
\end{tabular}

Table 4.3 above shows that $68 \%$ of those interviewed agree that qualified managers give quality service to Saccos. $17 \%$ were however neutral with $15 \%$ being in disagreement. Management qualification has also been rated highly on performance with $63 \%$ of those interviewed agreeing and no one was neutral. $29 \%$ however disagree and further $17 \%$ strongly feel that qualification does not necessarily cause improved performance.

Of the respondents interviewed $40 \%$ agree that management quality is of more benefit compared to cost, $11 \%$ are neutral. However $29 \%$ disagrees with this position and a further $17 \%$ strongly disagree.

Table 4.2.2 above show that $32 \%$ of those interviewed strongly agree that the qualified managers are more expensive for small Saccos with further 16\% being in agreement. $17 \%$ however strongly disagree with further $16 \%$ disagree and another $17 \%$ were neutral.

4.3.1 Spearman rank correlation on the relationship between management quality and qualification

Table 4.3.1 Spearman rank correlation on the relationship of factors

\begin{tabular}{|c|c|c|c|c|c|}
\hline & & $\begin{array}{l}\text { Quality } \\
\text { service }\end{array}$ & Qualification & $\begin{array}{c}\text { Cost } \\
\text { Benefit }\end{array}$ & Affordability \\
\hline \multirow{3}{*}{$\begin{array}{l}\text { Managers give quality service to } \\
\text { Saccos }\end{array}$} & C. Coefficient & 1 & $.625^{* *}$ & $.348^{*}$ & 0.22 \\
\hline & Sig. (1-tailed) & & 0 & 0.02 & 0.11 \\
\hline & $\mathrm{N}$ & 35 & 33 & 35 & 33 \\
\hline \multirow{3}{*}{$\begin{array}{l}\text { Managers qualification is important } \\
\text { for Saccos performance }\end{array}$} & C. Coefficient & 0.076 & 1 & 0.235 & 0.088 \\
\hline & Sig. (1-tailed) & 0.334 & 0.211 & 0.091 & 0.316 \\
\hline & $\mathrm{N}$ & 34 & 32 & 34 & 32 \\
\hline \multirow{3}{*}{$\begin{array}{l}\text { Management quality and require- } \\
\text { ment is of more benefit compared } \\
\text { to cost }\end{array}$} & C. Coefficient & $.291^{*}$ & $.342^{*}$ & 1 & 0.189 \\
\hline & Sig. (1-tailed) & 0.048 & 0.028 & 0.152 & 0.15 \\
\hline & $\mathrm{N}$ & 34 & 32 & 34 & 32 \\
\hline \multirow{3}{*}{$\begin{array}{l}\text { Qualified managers are expensive } \\
\text { for small Saccos }\end{array}$} & C. efficient & $.325^{*}$ & 0.253 & 0.162 & 1 \\
\hline & Sig. (1-tailed) & 0.031 & 0.081 & 0.179 & 0.299 \\
\hline & $\mathrm{N}$ & 34 & 32 & 34 & 32 \\
\hline
\end{tabular}

As indicated above the various factors associating with management quality requirement was analyzed. A result demonstrates that management performance has a significant correlation with all the factors evaluated. Manager's ways of handling issues was highly pegged on their qualification as shown in the table above. Profitability of the Sacco was also

highly correlated with management performance. Strong correlation of $95 \%$ confidence intervals was noted between the variables

The findings on efficiency and timeliness of qualified managers are in concurrence with Ralson et al (2001). The study found out that professionally run credit unions were stronger and more flexible unlike 
member run unions. Also on performance, the qualified managers are perceived to be more productive than their counterparts.

On strength of previous structures to enable smooth running of Saccos, the study was in contradiction with Ademba, 2011) as he found out that AGM was a tool of final decision making and board of directors as capable of running the Saccos. Most of those interviewed said that the previous struc- tures were weak or poor.

The findings on qualification of managers concurs with Wanyoike (2013) as she found out that qualifications should be upgraded for managers to have more qualifications. This study found out that the management performance directly links with their qualification with $63 \%$ being in agreement that the qualified managers were performers.

4.4 Membership Requirement by SASRA

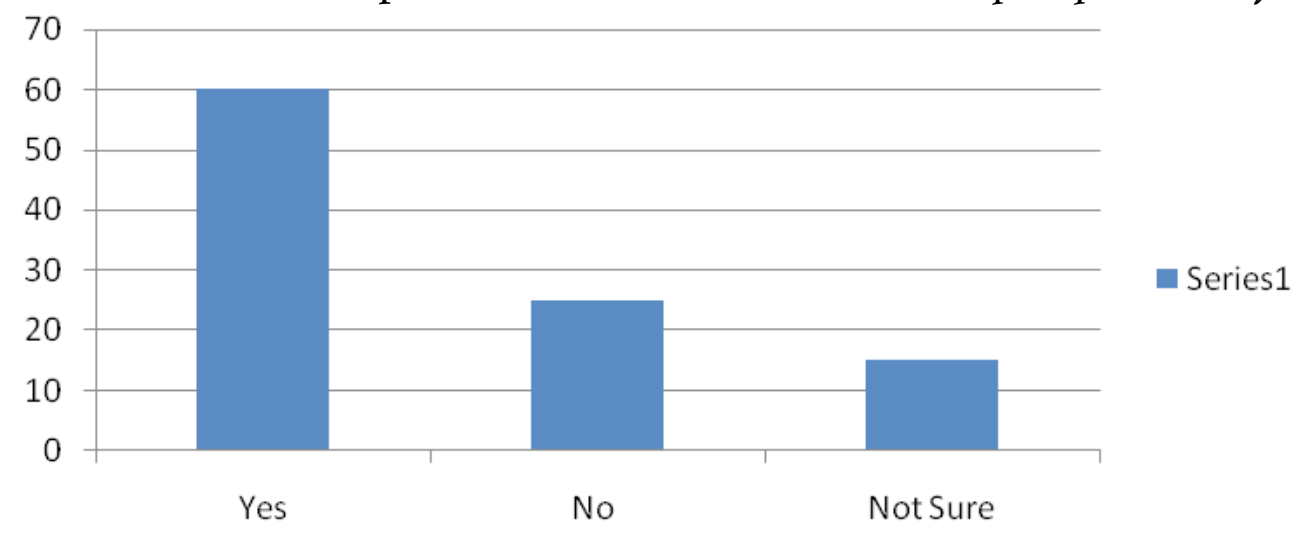

Figure 4.4 Support for the introduction of membership requirement

Of the respondents $60 \%$ of them support the introduction of membership requirement $25 \%$ were against the regulation and $15 \%$ are not sure. The findings of the study show that $60 \%$ of the respondents support the introduction of membership requirement that seeks to give Saccos homogeneous members. This is in agreement with Gordon (2002) whom in his study for better financial and social welfare, cooperatives should use common membership or goal oriented people to enhance wealth creation and more capital investment. This henceforth means that the regulation proposed will help in growing Saccos both in financial and profitability terms.

Table 4.4 Chi-Square Tests on support of the membership requirement

\begin{tabular}{|l|r|r|r|}
\hline & \multicolumn{1}{|l|}{ Value } & Df & Asymp. Sig. (2-sided) \\
\hline Pearson Chi-Square & $2.976^{\mathrm{a}}$ & 4 & .562 \\
\hline Likelihood Ratio & 3.655 & 4 & .455 \\
\hline Linear-by-Linear Association & 2.090 & 1 & .148 \\
\hline N of Valid Cases & 34 & & \\
\hline
\end{tabular}

a. 7 cells $(77.8 \%)$ have expected count less than 5 . The minimum expected count is .71 .

Table 4.4.1 membership requirement factors

\begin{tabular}{|l|l|l|l|l|l|l|}
\hline & SAgree & Agree & Neutral & Disagree & SDisagree & Total \\
\hline $\begin{array}{l}\text { Membership requirement has improved quality } \\
\text { of service to members }\end{array}$ & $34.30 \%$ & $31.40 \%$ & $14.30 \%$ & $14.30 \%$ & $5.70 \%$ & $100.00 \%$ \\
\hline $\begin{array}{l}\text { Membership requirement has reduced misman- } \\
\text { agement through close monitoring }\end{array}$ & $17.10 \%$ & $42.90 \%$ & $14.30 \%$ & $17.10 \%$ & $8.60 \%$ & $100.00 \%$ \\
\hline $\begin{array}{l}\text { The membership regulation is punitive to ex- } \\
\text { pansion of Saccos }\end{array}$ & $3.00 \%$ & $12.10 \%$ & $15.20 \%$ & $6.10 \%$ & $3.00 \%$ & $39.40 \%$ \\
\hline
\end{tabular}

Table 4.4 .1 above shows that $65 \%$ of those interviewed agree that membership requirement has improved services to members, $14 \%$ are however neutral with $5 \%$ strongly disagreeing and further $14 \%$ disagree. Also of the interviewed $8 \%$ strongly disagree that membership requirement has reduced mismanagement through close monitoring with $59 \%$ strongly agree with this position while $15 \%$ are neutral.

As per the table $4.4 .1,42 \%$ of those interviewed 
think that the membership requirement is punitive to Sacco expansion, $15 \%$ of the members however agree with this position with $6 \%$ being neutral.

The membership requirement however received minimal support by those interviewed. Most of them viewed the regulation as punitive as it works to reduce Sacco members and Sacco liquidity and earnings. This is in concurrence with Huppi and Fedder (2010) who concluded that Saccos have a pyramid effect and working to alter the pyramid shape at any level may lead to failure of the Sacco. Huppi and Fedder, (2010) also concluded that regulation of members will lead to reduction in default rate as familiar members will self-regulate. This is in contradiction with this study finding as the loan default was not reduced by the membership regulation requirement as it was expected that members would push each other to meet obligation as the failure of one member costs the others.

The study also found out that the membership requirement has not led to reduction of mismanagement. Close monitoring from 'members only' Saccos were expected to lower level of mismanagement. This is in line with (Muchemi 2005) whom in their study concluded that the one member one vote, the structure works to strengthen management and decision making and hence make or break the wealth acquisition aspiration of members by prudential board of management.

\subsubsection{Hypothesis Testing}

Ho: Statutory deposit fund requirement has no effect on performance of small Saccos in Kenya.

Regression results revealed that statutory deposit fund has effect on performance of small Saccos $(\beta$ 0.532 ; P value 0.014 and a t value 1.756 ) thus the null hypothesis had to be rejected. This implies that this factor has a direct effect on performance of small Saccos.

$\mathbf{H o}_{2}$ : Management qualification and quality has no effect on the performance of small Saccos in Kenya. Regression results revealewd that management qualification and quality has greater effect on performance ( $\beta$ 0.605; P value 0.009 and t value 6.231) and hence the null hypothesis was rejected. This implies that this factor has a direct effect on performance of small Saccos.

$\mathbf{H o}_{3}$ : Membership regulation requirements has no effect on performance of small Saccos in Kenya.
Regression results revealed that membership regulation requirement has effect on performance ( $\beta$ 0.788; P value 0.019 and $t$ value 3.762 ) and hence the null hypothesis was rejected. This implies that the factor has a greater effect on performance of small Saccos.

\subsection{Summary, Conclusion and Recommenda- tion}

\subsection{Summary of the Findings}

The study sought to investigate the effect of government regulation on performance of small Saccos in Nairobi City County. The first objective of the study was to investigate the effect of statutory deposit fund requirement on performance of small Saccos in Nairobi City County. The findings of the study reveal that statutory deposit fund requirement was a significant factor on performance of small Saccos in Nairobi City County.

The second objective investigated by the study was to determine the effect of management qualification on the performance of small Saccos in Nairobi City County. The analysis of data revealed a significant relationship between management qualification and performance of small Saccos.

Finally the study sought to determine the effect of membership regulation requirements on performance of small Sacco in Nairobi City County. Results from the study show a significant relationship between membership regulation requirements and performance of small Saccos.

\subsection{Conclusion}

The study has found out that the Sacco regulations have affected performance of small Saccos. Savings deposit requirement has improved confidence of members and hence lead to increase in savings which makes the Sacco more liquid to issue more loans and hence more profitable.

Management qualification requirement has made Sacco operation efficient and timely. The cost is however high and unaffordable to small Saccos but the tradeoff is positive. The membership requirement however has led to the reduction in the number of Sacco members and hence reduced deposits and business, making the Saccos less profitable. This is seen as a punitive measure to Sacco sector and hence emphasis needs to be concentrated to enable growth. 


\subsection{Recommendations}

In line with the study the following recommendations are made;

The statutory deposit requirement is important in safeguarding deposits of Sacco members and hence all Saccos should move to insure their clients' deposits. Small Saccos that view the deposit as out of reach should seek mergers to be able to comply with the regulation and avoid deregistration.

On membership requirement the Sacco movement should lobby to have the requirement amended as it is punitive and has led to the reduction in Sacco members and also loss of business for Saccos.

\section{References:}

1. Ademba Carrilus. (2011). Challenges facing Sacco Regulation in Africa. $11^{\text {th }}$ SACCA Congress: Swaziland.12 (1). P. 42-48.

2. ACCOSCA. (2008). The facts about Saccos in Africa. Saccos in Brief Quarterly Publication.

3. Andrew Baker. (2008). Credit Union Regulation and financial service Authority: Less is more, but better. International journal of law and management, Vol. 50:155:66 P. 301-315.

4. Be'roff Rene'e Chao (2008). Regulation and Supervision of Member-Owned Institutions in remote rural areas. Ford Foundation.

5. Chebor Moses (2008). Understanding Co-operative movement and its value. Green line Publishers. Nairobi Kenya.

6. Cunningham Lawrence A. (2007) A Prescription to Retire the Rhetoric of 'Principles-Based Systems' in Corporate Law, Securities Regulation and Accounting.

7. Drake Ford (2002).Coordinating policies and powers to reduce social exclusion”. The Welsh Approach to credit Union Development: the Wale Law Journal, Vol.1 No.3 P. 246-55.

8. Dernirguc Kunt, Edward |Kane and Luc Laven (2007) Measuring financial inclusion and reaction to changes.

9. Fischer Klaus P. and Cuevas Carols E. (2006). Co-operative financial institutions: issues in governance, regulation and supervision. World Bank Working Paper no 82.

10. Gordon V. Karels (2002). Deposit Insurance and Risk taking behavior in Sacco Industry. Interaction Book Company.

11. Gordon V. Karels \& McClatchey Christine A. (1999). Deposit insurance and risk-taking behavior in the credit union industry. Federal Reserve Bank of Atlanta working paper 2001-10, Journal of banking and finance (online).

12. Grossman Sanford J. and Hart D. Olive. (2002). One share-one vote and the market for cooperate control (online).

13. Honohan Bardo and L Klingebiel. (2003).Controlling costs of financial crisis through blanket guarantee. Journal of Banking and Finance 27: P. 1539-1560.

14. Huppi Monika and Feder Gershon. (2010). The role of groups and credit cooperative in rural lending. Oxford journals (online).

15. International Cooperatives Alliance ICA. (2013) Cooperatives and sustainable development goals.

16. International Cooperatives Alliance ICA. (2008) A report on the progress of credit unions in sub Sacco Regulatory Framework Workshop. Silver Springs Hotel. Nairobi Kenya.

17. KUSCCO LTD (2010).The history of Sacco movement in Kenya since early 1900. Sacco star issue 10. Color print media, Kenya.

18. Kumar Anjali, Paula Pertunen and Terry Mchuppe. (1997). Regulation of non-banking financial institutions. World Bank Discussion Paper no 362.

19. Kioko Kilonzi Benson. (2012) Impact of Sasra regulations on the financial performance of Saccos in Kenya, A case study. MBA Dissertation Unpublished. 
20. Kothari C. R. (2012). Research Methodology Methods and Techniques, New Age International publishers. 2nd ed. New Delhi New Age 1990.

21. Kotler Armstrong G. F. (2007). Marketing, An introduction 8th Ed, USA: Pearson Education.

22. McKillop D, Glass J. and Ferguson C. (2002)."Investigating the growth and performance of UK Credit Unions using radical and non-radical measures”. Journal of Banking and Finance, Vol.26 No.8 P.1563-91.

23. Muchemi Kuria Allan. (2005). Customers Retention Strategies in SACCOs. A case Study of Selected SACCOs in Kenya. Nairobi.

24. Njuguna Peter (2012). Impact of Sacco regulation on collection by Saccos. 2012 Accosca Sacca Congress Uganda.

25. Ochanda Muko. (2013) East African Counter Human Trafficking Efforts in Economy Enterprise and Livelihoods, Kenya, Poverty, Social enterpreneurship, Third Sector and Social Economy.

26. Pille Peter \& Paradi Joseph C. (2002). Financial Performance Analysis of Ontario (Canada) Credit Unions: An application of DEA in Regulatory Environment. European Journal of Operation Research

27. Rubambey Grace C. (2005) Policy on regulation and supervisory environment for microfinance in Tanzania. Essay on regulation and supervision. (online).

28. Wanyoike Serah Wangui (2013) Effect of compliance to Sasra Regulation on financial performance of Saccos in Kenya: A survey of Deposit taking Saccos in Nairobi County. MBA dissertation Unpublished.

29. World Bank (2004) Deposit Insurance- Reform supported by the World Bank during the period 19332004. Mimeo Operation Evaluation. The World Bank Washington DC.

30. Zeuli Kimberly and Robert Cropp. (2004) Principles and practice of Co-operatives in $21^{\text {st }}$ century. Wisconsin Publishing R-08-2004. 